\title{
ANALISIS REGRESI LOGISTIK FAKTOR-FAKTOR YANG MEMENGARUHI PENGGUNAAN ROKOK ELEKTRONIK PADA REMAJA USIA 18-25 TAHUN DI KOTA DENPASAR TAHUN 2020
}

\author{
Putu Pirda Puspitawati*, Desak Nyoman Widyanthini \\ Alamat: Program Studi Sarjana Kesehatan Masyarakat Fakultas Kedokteran Universitas Udayana
}

\begin{abstract}
ABSTRAK
Pengguna rokok tembakau di Kota Denpasar belum menurun dengan signifikan namun sudah muncul produk baru yaitu rokok elektronik. Proporsi pengguna rokok elektronik di Kota Denpasar saat ini 6.81\%. Tujuan penelitian ini untuk mengetahui faktor-faktor yang memengaruhi penggunaan rokok elektronik pada remaja usia 18-25 tahun di Kota Denpasar 2020. Penelitian ini merupakan analitik kuantitatif dengan rancangan crossectional study menggunakan metode convinience sampling. Sampel penelitian ini yaitu remaja berusia 18-25 tahun minimal tinggal 6 bulan di Kota Denpasar. Besar sampel minimal adalah 149 dengan jumlah partisipasi yaitu 201 responden. Penelitian ini mengumpulkan data karakteristik responden, perilaku merokok elektrik, faktor predisposisi, faktor penguat dan faktor pemungkin menggunakan kuesioner online kobotoolbox. Data dianalisis secara deskriptif dan hubungan antar variabel diuji dengan regresi logistic binary. Hasil penelitian ini menunjukan proporsi pengguna rokok elektronik pada remaja di Kota Denpasar sebesar 22.89\%. Variabel yang terbukti secara signifikan memiliki hubungan terhadap penggunaan rokok elektronik adalah paparan iklan rokok elektronik (OR=7.15; 95\% CI: 2.6119.59; $<<0.001)$, persepsi positif (OR=6.46; 95\% CI: 2.45-17.06; $<<0.001)$, jenis kelamin laki-laki (OR=6.25; 95\% CI: 2.41 8.22: $\mathrm{p}=0.001)$, keluarga menggunakan rokok elektronik $(\mathrm{OR}=4.17 ; 95 \% \mathrm{CI}$ : 1.71-10.11; $\mathrm{p}<0.005)$, keterjangkauan $(\mathrm{OR}=4.38 ; 95 \%$ CI 1.72-11.13; $\mathrm{p}=<0.005)$, teman sebaya menggunakan rokok elektronik (OR=477; 95\%CI:1.614.14; $\mathrm{p}<0.005)$ dan uang saku tinggi $(\mathrm{OR}=6.85 ; 95 \%$ 1.97-23.72; $\mathrm{p}<0.005)$. Penggunaan rokok elektronik di Kota Denpasar tergolong masih tinggi untuk itu diperlukan edukasi tentang bahaya rokok elektronik serta regulasi yang jelas terkait peredaran rokok elektronik.
\end{abstract}

Kata kunci: Rokok Elektronik, Remaja, Perilaku Merokok, Regresi Logistik

\section{ABSTRACT}

Tobacco cigarette users in Denpasar City have not decreased significantly, but there is the emergence of new products, which is electronic cigarettes. The proportion of electronic cigarette users in Bali Province is $6,81 \%$. This study aimed to determine the factors that influence the use of electronic cigarettes in adolescents aged 18-25 years in Denpasar City 2020.This study is a quantitative analytic study with a cross-sectional design using conviniece sampling method. The sample of this study is adolescents aged 18-25 years living for a minimum of 6 months in Denpasar City. The minimum sample size is 149 respondents with a total participation of 201 respondents. This study collected data on the characteristics of respondents, electric smoking behavior, predisposing factors, amplifier factors, supporting factors using the online questionnaire (kobotoolbox). Data were analyzed descriptively and the relationship between variables was tested by binary logistic regression. The variables that have been shown to have a significant relationship to the use of electronic cigarettes in Denpasar City is $22,89 \%$. The variable are exposure have significant relationship among the use of electronic cigarettes is electronic cigarette advertisements ( $\mathrm{OR}=7.15 ; 95 \% \mathrm{CI}: 2.61-19.59 ; \mathrm{p}<0.001)$, positive perception $(\mathrm{OR}=6.46$; 95\% CI: 2.45-17.06; $\mathrm{p}$ $<0.001)$, male gender $(\mathrm{OR}=6.25 ; 95 \% \mathrm{CI}: 2.41-8.22: \mathrm{p}=0.001)$, families using electronic cigarettes $(\mathrm{OR}=4.17 ; 95 \% \mathrm{CI}$ : $1.71-10.11 ; \mathrm{p}<0.005)$, affordability ( $\mathrm{OR}=4.38 ; 95 \% \mathrm{CI} 1.72-11.13 ; \mathrm{p}=<0.005)$, peers use electronic cigarettes $(\mathrm{OR}=$ 477; 95\% CI: 1.6-14.14; $\mathrm{p}<0.005$ ) and high allowance ( $\mathrm{OR}=6.85 ; 95 \% 1.97-23.72 ; \mathrm{p}<0.005)$. The use of electronic cigarettes in Denpasar has high, so education about the dangers of electronic cigarettes is needed as well as clear regulations related to electronic cigarettes.

Keywords: Electronic Cigarette, Adolescent, Behaviour, Logistic Regression.

\section{PENDAHULUAN}

Penggunaan tembakau saat ini masih menjadi permasalahan disetiap negara. Indonesia merupakan salah satu negara berkembang dengan jumlah perokok dewasa 65.19 juta orang dan menempati 
peringkat pertama pengguna rokok di negara-negara Association of Southeast Asian Nations (ASEAN) (Lian and Dorotheo, 2018). The Tobacco Control Altlas menyebutkan secara global merokok menyebabkan 7 juta orang meninggal setiap tahunnya (Lian and Dorotheo, 2018).

Konsumsi tembakau di Indonesia masih tergolong tinggi, hal ini disebabkan oleh industri tembakau yang semakin berkembang menyebabkan pro dan kontra, dimana industri tembakau di Indonesia memberikan lapangan pekerjaan 6.1 juta orang (Ditjen Bea Cukai, 2011). Terdapat perjanjian yang diberi nama Framework Convention On Tobacco Control (FCTC) merupakan suatu perjanjian international yang melindungi generasi muda dari dampak rokok. Perjanjian ini sudah ditandatangani lebih dari 180 negara, namun negara Indonesia belum melakukan aksesi dengan pertimbangan keberadaan petani tembakau, dan penyerapan tenaga kerja (WHO,2020).

Berdasarkan data (Kementerian Kesehatan RI, 2013) proporsi perokok di Indonesia pada usia $\geq 10$ tahun sebesar 29.3\% sebagian besar pengguna rokok pada usia produktif, sedangkan pada data Kementerian Kesehatan RI (2018) mengalami penurunan menjadi sebesar 24.3\%. Proporsi merokok di Provinsi Bali tahun 2013 sebesar 22.4\% dan tahun 2018 mengalami penurunan sebesar 3.5\% menjadi 18.9\% (Kementerian Kesehatan RI, 2018). Pengguna tembakau di Indonesia saat ini belum mengalami penurunan yang signifikan, namun sudah munculnya

Email korespondensi: puspitapirda14@gmail.com produk baru antara lain electronic cigarette dan heated tobacco product (HTP).

Proporsi pengguna rokok elektronik di Indonesia yaitu sebesar $2.8 \%$ (Kementerian Kesehatan RI, 2018). Pemasaran untuk produk rokok elektronik belum memberikan informasi yang pasti terkait kandungan dari rokok tersebut. Sehingga BPOM maupun kementerian kesehatan belum bisa mengawasi peredaran rokok elektronik. Proporsi pengguna rokok elektronik di Provinsi Bali sebesar 4.2\%. Kota Denpasar menempati peringkat ketiga tertinggi pengguna rokok elektronik setelah Kabupaten Bangli yakni sebesar 6.81\% (Kementerian Kesehatan RI, 2018).

Pengguna rokok elektronik didominasi oleh kelompok usia muda. Adanya peningkatan pengguna rokok elektronik pada usia remaja dilihat dari penelitian Putra et al (2017) pengguna rokok elektronik sebesar 20.5\% dan pada penelitian (Devhy and Yudari, 2017) proporsi pengguna rokok elektronik 25.29\%. Usia 17-25 tahun merupakan usia yang rentan menggunakan rokok elektronik dilihat dari penelitian yang dilakukan di Kota Semarang dengan menyasar pengguna rokok elekronik menyebutkan bahwa proporsi pengguna rokok elektronik sebagian besar pada usia (17-25 tahun) sebesar 65.6\% (Istiqomah et al., 2016).

Untuk mengkaji faktor-faktor yang memengaruhi penggunaan rokok elektronik, salah satu framework yang dapat digunakan yaitu teori precede proceed perilaku dari Lawrencegreen tahun 1980. Dimana dalam teori ini melihat perilaku 
Arc. Com. Health • Agustus 2021 p-ISSN 2302-139X e-ISSN 2527-3620

kesehatan yang dipengaruhi oleh tiga faktor yaitu faktor predisposisi, penguat dan faktor pemungkin. Adapun faktor predisposisi yaitu persepsi seperti penggunaan rokok elektronik lebih aman,, dapat membantu berhenti merokok, dan tidak dibatasi di area publik memiliki (Bigwanto et al., 2019). Selanjutnya faktor penguat yaitu memiliki teman sebaya menggunakan rokok elektronik. Penelitian Pitriyanti et al (2018) dari hasil analisis faktor memiliki teman sebaya mengunakan rokok elektronik mempunyai hubungan yang bermakna statistik dengan penggunaan rokok elektronik. Penelitian di Jerman menunjukan sebagian besar remaja terpapar oleh iklan rokok elektronik dan terdapat hubungan positif antara paparan iklan dengan penggunaan rokok elektronik (Hansen et al., 2018). Selanjutnya faktor pemungkin pada penelitian di Jakarta yaitu memiliki uang yang cukup. Proporsi pengguna rokok elektronik yang memiliki uang yang cukup untuk membeli rokok elektronik sebesar 41.8 \% (Bigwanto et al., 2019).

Untuk mengetahui hubungan dari faktor-faktor tersebut maka digunakan uji analisis regresi logistik. Regresi logistik berfungsi untuk mengetahui hubungan antara satu variabel outcome dengan satu atau lebih variabel bebas. Parameter yang dipakai untuk menilai hubungan tersebut yaitu Odd Ratio (OR). Berdasarkan pemaparan diatas peneliti tertarik untuk mengetahui faktor-faktor penggunaan rokok elektronik pada remaja usia 18-25 tahun Kota Denpasar Tahun 2020 dengan menyebarkan kuesioner penelitian pada remaja yang dipilih peneliti melalui kontak Email korespondensi: puspitapirda14@gmail.com
Vol. 8 No. 2: 237 - 253

menggunakan analisis regresi logistik. Hal ini menjadi penting karena penelitian tentang faktor-faktor yang memengaruhi penggunaan rokok elektronik remaja usia 18-25 tahun di Kota Denpasar belum pernah diteliti selain itu pengguna rokok elektronik meningkat setiap tahunnya.

\section{METODE PENELITIAN}

Penelitian ini menggunakan rancangan crossectional study untuk mengetahui faktor-faktor yang berhubungan penggunaan rokok elektronik. Penelitian ini dilakukan selama enam bulan di Kota Denpasar dari Bulan Januari sampai dengan Bulan Juni 2020. Teknik pengambil sampel menggunakan metode convinience sampling dengan minimal jumlah sampel 149 orang. Populasi terjangkau dalam penelitian ini yaitu remaja (18-25 tahun) tinggal di Kota Denpasar minimal enam bulan terakhir. Instrument Intrumen yang digunakan dalam penelitian ini adalah kuesioner online yang dimuat dalam aplikasi kobotoolbox. Kuesioner ini memuat pertanyaan-pertanyaan yang diteliti seperti faktor sosiodemografi, tingkat pengetahuan, persepsi, faktor memiliki teman sebaya menggunakan rokok elektronik, faktor memiliki keluarga menggunakan rokok elektronik, paparan iklan rokok elektronik, keterjangkauan. Kuesioner ini fungsinya untuk mengukur faktor-faktor yang memengaruhi penggunaan rokok elektronik di Kota Denpasar Pengumpulan data

Whatsapp, Line dan Instagram. Analisis data yang digunakan yaitu analisis regresi 
logistik sederhana (Simple logistic regression) akan menampilkan Odds Ratio (OR), nilai 95\% Confidence Interval (CI). Selanjutnya analisis multivariat yang digunakan yaitu regresi logistik binary (Binary logistic regression) dengan teknik eliminasi enter.

\section{HASIL PENELITIAN}

Remaja dalam penelitian ini berjumlah 201, sebagian besar remaja berumur 22-25 tahun (56.22\%) dan berumur 18-21 tahun 43.78\%. Proporsi remaja dalam penelitian ini dominan berjenis kelamin laki-laki yaitu $58.71 \%$. Mayoritas berpendidikan perguruan tinggi $50.75 \%$. Dilihat dari status pekerjaan remaja sebagian besar tidak bekerja $54.73 \%$, remaja yang bekerja berjumlah 91 orang dan sebagian besar mendapatkan penghasilan rendah sebesar $37.36 \%$, sedang (35.16\%) dan tinggi $27.47 \%$. Uangsaku yang diterima remaja sebagian besar tergolong tinggi yaitu 52.74, dan penghasilan kedua orang tua responden lebih banyak dalam katagori rendah $48.76 \%$.

Dilihat dari merokok pada remaja, $16.92 \%$ merupakan pengguna rokok elektronik saja, pengguna rokok tembakau $10.95 \%$, perokok ganda atau sering disebut dual smoker $5.97 \%$ dan terdapat mantan perokok sebesar 3.95\%. Perokok ganda merupakan pengguna rokok elektronik dan tembakau secara bersamaan. Jumlah total yang menggunakan rokok elektronik sebesar $22.89 \%$. Rata-rata penggunaan rokok elektronik selama 14 bulan, sedangkan yang paling lama yaitu 72 bulan. Rata-rata penggunaan liquid sebanyak $120 \mathrm{ml}$ perbulan dengan presentase dripping/hari dalam kategori berat yaitu $67.39 \%$. Rata-rata pembelian device sejak menggunakan rokok elektronik yaitu 7 buah dengan rata-rata pengeluaran untuk membeli satu buah device Rp. 508.000 dan rata-rata pengeluaran sebulan untuk rokok elektronik yaitu Rp.190.000.

Jumlah total pengguna rokok tembakau pada remaja sebesar $16.92 \%$, dimana rata-rata penggunaan rokok tembakau selama 32 bulan, dan meghabiskan rata-rata 7 batang rokok per minggu. Pengeluaran rata-rata untuk membeli rokok tembakau yaitu Rp. 253.000 perbulan. Terdapat presentase mantan perokok sebesar $(6.02 \%)$ dengan rata-rata sudah mulai berhenti merokok tembakau atau elektronik selama 10 bulan. Adapun beberapa alasannya yaitu tidak bisa menyelesaikan masalah sehingga memilih untuk berhenti mengonsumsi rokok elektronik maupun tembakau dan alasan lainnya karena ingin menurunkan risiko terpapar Covid19.

Tabel 1 Gambaran Katakteristik Sosal-Demografi dan Status Merokok Remaja

\begin{tabular}{lcc}
\hline \multicolumn{1}{c}{ Karakteristik (n=201) } & Frekuensi & Proporsi (\%) \\
\hline Umur & & \\
22-25 Tahun & 113 & 56.22 \\
18-21 Tahun & 88 & 43.78 \\
$\begin{array}{l}\text { Jenis Kelamin } \\
\text { Laki-laki }\end{array}$ & 118 & 58.71 \\
\hline
\end{tabular}

Email korespondensi: puspitapirda14@gmail.com 
Arc. Com. Health • Agustus 2021 p-ISSN 2302-139X e-ISSN 2527-3620

Perempuan

Pendidikan Terakhir

Perguruan Tinggi

SMA

\section{Status Pekerjaan}

Bekerja

Tidak Bekerja

Penghasilan $(n=91)$

Sedang

Tinggi

Rendah

Uang Saku

Rendah

Tinggi

Tidak ada

\section{Penghasilan Orang Tua}

Sedang

Tinggi

Rendah

Status Merokok

Rokok Elektronik

Rokok Tembakau

Rokok Ganda (Elektronik\&Tembakau)

Tidak Merokok

Mantan Perokok

Dripping $(\mathrm{n}=46)$

Berat (12-20 dripping/hari)

Ringan (3-11 dripping/hari)

Alasan Berhenti Merokok $(n=8)$

Mulai muncul tanda penyakit akibat rokok

Dilarang orang tua/keluarga

Atas kesadaran sendiri

Lainnya. sebutkan.......
83

41.29

102

50.75

99

49.25

91

45.27

110

54.73

32

35.16

25

27.47

34

37.36

31

15.42

106

52.74

64

31.84

84

41.79

19

9.45

98

48.76

34

16.92

22

10.95

12

5.97

125

62.19

8

3.98

15

32.61

31

67.39

1

12.5

0

0.0

4

50.0

3

37.5

Tabel 2. Hubungan dari Faktor- Faktor Predisposisi terhadap Penggunaan Rokok Elektronik pada Remaja

\begin{tabular}{lccccc}
\hline \multirow{2}{*}{ Variabel } & Ya & Tidak & OR & 95\%CI & P \\
\cline { 2 - 3 } & $\mathbf{( n = 4 6 )}$ & $\mathbf{( n = 1 5 5 )}$ & & & \\
\hline Umur & & & & & \\
22-25 Tahun & $30(26.55 \%)$ & $83(73.45 \%)$ & 1.62 & $0.82-3.22$ & 0.163 \\
$\begin{array}{c}\text { 18-21 Tahun } \\
\text { Jenis Kelamin } \\
\quad 16(18.18 \%)\end{array}$ & $72(81.82 \%)$ & Ref & & \\
Laki-laki & $38(32.20 \%)$ & $80(67.80 \%)$ & 4.45 & $1.95-10.16$ & 0.000 \\
\hline
\end{tabular}

Email korespondensi: puspitapirda14@gmail.com 


\begin{tabular}{|c|c|c|c|c|c|}
\hline Perempuan & $8(9.64 \%)$ & 75 (90.36\%) & Ref & & \\
\hline \multicolumn{6}{|l|}{ Pendidikan } \\
\hline \multicolumn{6}{|l|}{ Terakhir } \\
\hline Perguruan & $26(25.49 \%)$ & $76(74.51 \%)$ & 1.35 & $0.69-2.62$ & 0.373 \\
\hline \multicolumn{6}{|l|}{ Tinggi } \\
\hline SMA & $20(20.20 \%)$ & $79(79.80 \%)$ & Ref & & \\
\hline \multicolumn{6}{|l|}{ Status Pekerjaan } \\
\hline Bekerja & $16(17.58 \%)$ & $75(82.42 \%)$ & 0.56 & $0.28-1.12$ & 0.106 \\
\hline Tidak Bekerja & $30(27.27 \%)$ & $80(72.73 \%)$ & Ref & & \\
\hline \multicolumn{6}{|l|}{ Penghasilan } \\
\hline Sedang & $7(21.88 \%)$ & $25(78.13 \%)$ & 2.89 & $0.67-12.35$ & 0.151 \\
\hline Tinggi & $6(24.00 \%)$ & $19(76.00 \%)$ & 3.26 & $0.72-14.60$ & 0.122 \\
\hline Rendah & $3(8.82 \%)$ & 31 (91.18\%) & Ref & & \\
\hline \multicolumn{6}{|l|}{ Uang Saku } \\
\hline Rendah & $8(25.81 \%)$ & $23(74.19 \%)$ & 3.36 & $1.05-10.76$ & 0.041 \\
\hline Tinggi & $32(30.19 \%)$ & $74(69.81 \%)$ & 4.18 & $1.63-10-67$ & 0.003 \\
\hline Tidak ada & $6(9.38 \%)$ & $58(90.63 \%)$ & Ref & & \\
\hline \multicolumn{6}{|l|}{ Penghasilan } \\
\hline \multicolumn{6}{|l|}{ Orang Tua } \\
\hline Sedang & $21(25.00 \%)$ & $63(75.00 \%)$ & 1.08 & $0.55-2.14$ & 0.810 \\
\hline Tinggi & $2(10.53 \%)$ & $17(89.47 \%)$ & 0.38 & $0.08-1.78$ & 0.222 \\
\hline Rendah & $23(23.47)$ & $75(76.53 \%)$ & ref & & \\
\hline \multicolumn{6}{|l|}{ Pengetahuan } \\
\hline Kurang & $10(16.95 \%)$ & $49(83.05 \%)$ & 0.60 & $0.27-1.30$ & 0.200 \\
\hline Baik & $36(25.35 \%)$ & $106(74.65 \%)$ & ref & & \\
\hline \multicolumn{6}{|l|}{ Persepsi } \\
\hline Positif & $30(33.33 \%)$ & $60(66.67 \%)$ & 2.96 & $1.49-5.90$ & 0.002 \\
\hline Negatif & $16(14.41 \%)$ & $95(85.59 \%)$ & ref & & \\
\hline
\end{tabular}

Tabel 3. Hubungan dari Faktor- Faktor Penguat terhadap Penggunaan Rokok Elektronik pada Remaja

\begin{tabular}{lccccc}
\hline \multicolumn{1}{c}{ Variabel } & Ya & Tidak & OR & $\mathbf{9 5 \% C I}$ & $\mathbf{p}$ \\
\cline { 2 - 3 } & $\mathbf{( n = 4 6 )}$ & $\mathbf{( n = 1 5 5 )}$ & & & \\
\hline $\begin{array}{l}\text { Teman Sebaya } \\
\text { Ya }\end{array}$ & $38(29.92 \%)$ & $89(70.02 \%)$ & $\begin{array}{r}3.52 \\
\text { ref }\end{array}$ & $1.54-8.04$ & 0.003 \\
$\quad \begin{array}{l}\text { Tidak } \\
\text { Keluarga }\end{array}$ & $8(10.81 \%)$ & $66(89.19 \%)$ & & \\
$\quad$ Ya & $28(36.84 \%)$ & $48(63.16 \%)$ & 3.46 & $1.75-6.86$ & 0.000 \\
$\quad$ Tidak & $18(14.40 \%)$ & $107(85.60 \%)$ & ref & & \\
$\begin{array}{l}\text { Iklan } \\
\quad \text { Ya }\end{array}$ & $31(35.63 \%)$ & $56(64.37 \%)$ & 3.65 & $1.81-7.34$ & 0.000 \\
$\quad$ Tidak & $15(13.16 \%)$ & $99(86.84 \%)$ & ref & & \\
\hline
\end{tabular}

Tabel 4. Hubungan dari Faktor- Faktor Pemungkin terhadap Penggunaan Rokok Elektronik

\begin{tabular}{cccccc} 
pada Remaja & & & & & \\
\hline Variabel & Ya & Tidak & OR & $95 \% C I$ & $p$
\end{tabular}




\section{$(n=46) \quad(n=155)$}

\begin{tabular}{lccccc}
\hline Keterjangkauan & & & & & \\
Terjangkau & $29(32.95 \%)$ & $59(67.05 \%)$ & 2.77 & $1.40-5.48$ & 0.003 \\
Tidak Terjangkau & $17(15.04 \%)$ & $96(84.96 \%)$ & ref & & \\
\hline
\end{tabular}

Berdasarkan analisis bivariabel pada Tabel. 2, Tabel. 3 dan Tabel. 4 didapat hasil tujuh variabel yang mempunyai hubungan bermakna dengan penggunaan rokok elektronik. Ditinjau dari faktor sosiodemografi, variabel yang berhubungan dengan penggunaan rokok elektronik yaitu jenis kelamin $(p<0.001)$, dan uang saku $(\mathrm{p}<0.05)$. Proporsi pengguna rokok elektronik dilihat dari jenis kelamin laki-laki sebesar $32.20 \%$ sedangkan yang berjenis kelamin perempuan $9.64 \%$. selanjutnya hubungan uang saku dengan pengguna rokok elektronik, dilihat dari proporsi pengguna rokok elektronik yang mendapatkan uang saku tinggi yaitu 30.19, uang saku rendah $(25.81 \%)$ dan yang tidak mendapatkan uang saku (9.38\%). Adapun faktor-faktor sosiodemografi yang tidak mempunyai hubungan signifikan $(p>0.05)$ yaitu umur, pendidikan terakhir, pekerjaan, dan penghasilan orang tua.

Pada Tabel. 2 yaitu faktor predisposisi terdiri dari faktor sosiodemografi, persepsi dan pengetahuan. Proporsi pengguna rokok elektronik yang berpengetahuan baik sebesar $25.35 \%$ dan proporsi kurang baik sebesar $16.95 \%$. Dalam penelitian ini pengetahuan tidak memiliki hubungan yang signifikan terhadap penggunaan rokok elektronik $(p>0.05)$. Selanjutnya, faktor persepsi dalam penelitian ini dibagi menjadi dua kategori yaitu persepsi positif dan negatif. Persepsi positif apabila Email korespondensi: puspitapirda14@gmail.com responden menjawab $>50 \%$ setuju maupun sangat setuju sedangkan persepsi negatif apabila responden menjawab setuju maupun sangat setuju $\leq 50 \%$. Proporsi pengguna rokok elektronik yang memiliki persepsi positif yaitu $33.33 \%$ sedangkan yang memiliki persepsi negatif (14.41\%). Terdapat hubungan antara persepsi terhadap rokok elektronik $(p<0.05)$.

Pada Tabel. 3 yaitu Faktor penguat dalam penelitian ini terdiri dari faktor teman sebaya, keluarga, dan paparan iklan. Dilihat dari faktor teman sebaya, proporsi penggunaan rokok elektronik yang memiliki teman merokok elektronik sebesar $(29.92 \%)$ sedangkan yang tidak memiliki teman merokok (10.81\%). Faktor teman saya berhubungan signifikan terhadap penggunaan rokok elektronik $(p<0.05)$ Selanjutnya proporsi pengguna rokok elektronik yang juga memiliki keluarga merokok elektronik yaitu 36.84\% dan yang tidak memiliki keluarga merokok $14.40 \%$. Faktor keluarga berhubungan signifikan terhadap penggunaan rokok elektronik $\quad(p<0.001)$. Paparan iklan merupakan salah satu variabel dalam penelitian ini, dimana hasil analisis menunjukan proporsi pengguna rokok elektronik yang terkena paparan iklan sebesar $35.63 \%$ dan yang tidak terpapar $13.16 \%$. Paparan iklan berhubungan signifikan terhadap penggunaan rokok elektronik ( nilai $\mathrm{p}<0.001$ ). 
Pada Tabel. 3 merupakan faktor pemungkin dalam penelitian ini yaitu keterjangkauan dimana proporsi remja yang merokok elektronik berasumsi rokok elektronik terjangkau sebesar 32.95\% dan tidak $\quad 15.04 \%$. keterjangkauan berhubungan signifikan dengan penggunaan rokok elektronik dimana bila remaja berasumsi terjangkau berpeluang meningkatkan penggunaan rokok elektronik 2.77 daripada tidak terjangkau (OR:2.77; 95\%CI 1.40-5.48

Tabel 5. Analisis Multivariat Faktor-Faktor yang Berhubungan dengan Penggunaan Rokok Elektronik

\begin{tabular}{|c|c|c|c|}
\hline Variabel & OR & $95 \%$ CI & $\mathbf{P}$ \\
\hline \multicolumn{4}{|l|}{ Jenis Kelamin } \\
\hline Laki-Laki & 6.25 & $2.41-8.22$ & 0.001 \\
\hline Perempuan & ref & & \\
\hline \multicolumn{4}{|l|}{ Keluarga } \\
\hline Ya & 4.17 & $1.71-10.11$ & 0.002 \\
\hline Tidak & ref & & \\
\hline \multicolumn{4}{|l|}{ Iklan } \\
\hline Pernah & 7.15 & 2.61-19.59 & 0.000 \\
\hline Tidak Pernah & ref & & \\
\hline \multicolumn{4}{|l|}{ Persepsi } \\
\hline Positif & 6.46 & $2.45-17.06$ & 0.000 \\
\hline Negatif & ref & & \\
\hline \multicolumn{4}{|l|}{ Teman Sebaya } \\
\hline Ya & 4.77 & $1.6-14.14$ & 0.005 \\
\hline Tidak & ref & & \\
\hline \multicolumn{4}{|l|}{ Keterjangkauan } \\
\hline Terjangkau & 4.38 & $1.72-11.13$ & 0.002 \\
\hline Tidak Terjangkau & Ref & & \\
\hline \multicolumn{4}{|l|}{ Uang saku } \\
\hline Rendah & 4.25 & $0.87-20.75$ & 0.074 \\
\hline Tinggi & 6.85 & $1.97-23.72$ & 0.002 \\
\hline Tidak ada & ref & & \\
\hline$R^{2}$ & 0.39 & & \\
\hline
\end{tabular}


Hasil dari akhir model pada analisis multivariable menunjukan yang paling berhubungan persepsi berhubungan signifikan terhadap penggunaan rokok elektronik dimana persepsi positif memiliki peluang 6.46 kali lebih besar dibandingkan yang memiliki persepsi negatif Selanjutnya faktor iklan rokok elektronik berhubungan signifikan dengan penggunaan rokok elektronik dimana yang terpapar iklan memiliki peluang 7.15 kali lebih besar dibandingkan yang tidak terpapar iklan untuk menggunakan rokok elektronik Jenis kelamin merupakan faktor ketiga yang berhubungan dengan penggunaan rokok elektronik hubungan yang signifikan antara faktor jenis kelamin dengan penggunaan rokok elektronik dimana laki-laki berpeluang 6.25 kali lebih besar dibandingkan perempuan untuk menggunakan rokok elektronik. Dilihat dari faktor keluarga berhubungan signifikan dengan penggunaan rokok elektronik dimana keluarga yang merokok elektronik memiliki peluang 4.17 kali lebih besar dibandingkan tidak memiliki keluarga yang merokok. keterjangkauan berhubungan signifikan terhadap penggunaan rokok elektronik dimana kategori terjangkau 4.38 memiliki peluang lebih besar dibandingkan yang tidak terjangkau. salah satu faktor penguat yaitu teman sebaya memiliki hubungan yang signifikan terhadap penggunaan rokok dimana remaja yang memiliki teman sebaya yang merokok elektronik berpeluang 4.77 kali meningkatkan penggunaan rokok elektronik dibandikan remaja yang tidak mempunyai teman merokok elektronik. Faktor uang saku berhubungan signifikan terhadap penggunaan rokok elektronik dimana uang saku tinggi berpeluang 6.85 kali lebih besar daripada tidak mendapat uang saku. Uji goodness of fit dalam penelitianini menyhatakan model ini secara bermakna menggambarkan penggunaan rokok elektronik pada remaja dan data ini cocok dianalisis dengan regresi logistik dengan nilai estat gof 0.98 ( $\mathrm{p}>0.05)$. hasil pseudo $\mathrm{R}^{2}$ menunjukan bahwa kemampuan variabel bebas dalam menjelaskan variabel tergantung sebesar 0.39 atau $39 \%$.

\section{DISKUSI}

Pada penelitian didapatkan hasil proporsi remaja berusia 18-25 tahun yang menggunakan rokok elektronik di Denpasar saat ini $22.89 \%$. Pengguna rokok elektronik lebih banyak pada usia 22-25 tahun (26.55\%), perokok elektronik didominasi oleh kaum laki-laki yaitu $32.20 \%$,rata-rata menyelesaikan pendidikan Sekolah Menengah Atas (20.20\%) dan Perguruan Tinggi (25.49\%) Dari seluruh pengguna rokok elektronik, $67.39 \%$ merupakan kategori dripping ringan dan $32.61 \%$ dripping berat. Rata-rata penggunaan rokok elektronik 14 bulan dan yang paling lama yaitu 72 bulan. Pengisian liquid rata-rata setiap bulannya $120 \mathrm{ml}$, dan rata-rata pembelian device hingga saat ini yaitu 7 buah. Gencarnya pemasaran rokok elektronik menyebabkan adanya peningkatan konsumsi rokok elektronik. Pada data Risksdas (2018) proporsi penggunaan rokok elektronik di Kota Denpasar yaitu $6.8 \%$. Peningkatan penggunaan rokok elektronik dilihat dari 
penelitian Putra et al (2017) menggunakan sampel siswa SMA di Kota Denpasar mendapatkan hasil sebesar 20.5\%, selanjutnya penelitian Luh et al (2017) pengguna rokok elektronik $22.7 \%$ pada siswa SMA, dan penelitian Pitriyanti (2018) proporsi mahasiswa yang pernah menggunakan rokok elektronik sebesar $17.38 \%$. Peningkatan pengguna rokok rokok elektronik dikarenakan lebih dari sepertiga remaja (43.28\%) berpersepsi positif yaitu menganggap rokok elektronik sebagai alat untuk berhenti merokok tembakau, hal ini didukung oleh penelitian Pitriyanti et al ( 2018) yang mendapatkan hasil alasan menggunakan rokok elektronik sebagai alat untuk berhenti merokok tembakau. Adanya kemunculan rokok elektronik memungkinkan remaja untuk menjadi dual smoker, dengan menjadi pengguna rokok tembakau dan rokok elektronik secara bersamaan. Penelitian dari Cooper et al (2016) mengatakan pengguna rokok ganda atau dual smoker dipengaruhi oleh orang terdekat baik teman sebaya maupun keluarga. Selain itu, penelitian ini juga mengemukakan bahwa remaja dapat mengambangkan perilaku merokok ganda dan kepercayaan berdasarkan pengaruh sosial dan paparan rokok. Hasil penelitian yang dilakukan di Kota Denpasar diperoleh dual smoker pada remaja di sebesar $6 \%$.

\section{Faktor Predisposisi}

Karakteristik remaja dilihat dari analisis bivariate dan multivariat jenis kelamin berhubungan signifikan dengan penggunaan rokok elektronik dimana proprsi pengguna rokok elektronik lebih banyak pada kaum laki-laki 32.20\%, sedangkan perempuan $9.64 \%$. Jenis kelamin laki-laki berpeluang 6.25 kali lebih besar menggunakan rokok elektronik dibandingkan perempuan. Asumsi dari peneliti di Provinsi Bali sendiri sangat kental akan budaya sehingga menimbulkan perbedaan peran sosial antara laki-laki dan perempuan hal ini didukung oleh penelitian yang mengatakan laki-laki cenderung lebih bisa menyesuaikan sikap terhadap pengaruh lingkungan dan mempunyai jiwa rasa ingin tahu yang tinggi (Putro, 2017). Suhardi (1997) dalam Sulistyawan (2012) menyebutkan lebih banyak perilaku merokok pada laki-laki dan sedikit pada perempuan hal ini dikarenakan budaya yang kurang menerima perlaku merokok pada perempuan.

Karakteristik remaja dilihat dari variabel pendidikan tidak berhubungan signifikan terhadap penggunaan rokok elektronik. Proporsi pengguna rokok elektronik yang mempunyai pendidikan terakhir SMA yaitu $20.20 \%$ sedangkan yang memiliki pendidikan terakhir perguruan tinggi $25.49 \%$. Hasil penelitian ini sejalan dengan penelitian di Semarang dengan sampel yang tertinggi berpendidikan peguruan tinggi, menyebutkan bahwa tidak ada hubungan pendidikan terakhir dengan penggunaan rokok elektronik (Istiqomah et al.,2016). Asumsi peneliti dari hasil penelitian ini yaitu tingkat pengetahuan seseorang dipengaruhi oleh tingkat pendidikannya, namun hasil dari penelitian ini menunjukan lebih dari setengah remaja yang memiliki pengetahuan baik yang artinya tinggi maupun rendah pendidikan remaja tidak mempengaruhi niat untuk berperilaku merokok. Hal ini didukung oleh penelitian Sutfin et al (2014) yang mengatakan bahwa pendidikan tinggi 
maupun rendah belum tentu mengurungkan niat dalam pengambilan keputusan berperilaku merokok.

Proporsi pengguna rokok elektronik yang bekerja $17.58 \%$ dan yang tidak bekerja $27.27 \%$. Hasil yang diperoleh dari penelitian ini bahwa status pekerjaan tidak berhubungan signifikan dengan penggunaan rokok elektronik. Penelitian ini sejalan dengan penelitian yang dilakukan di Kota Semarang bahwa pekerjaan seseorang tidak menentukan penggunaan rokok elektronik (Istiqomah et al., 2016). Orang yang sedang mencari pekerjaan cenderung mengalami stress. Perilaku erokok biasanya disebabkan oleh beberapa faktor salah satunya faktor psikososial yaitu stress atau tekanan negatif dari lingkungan luar (Pitriyanti, 2018).

Pada hasil ini menunjukan proporsi yang berpenghasilan rendah sebesar $8.82 \%$, penghasilan sedang $24 \%$ dan berpenghasilan tinggi $21.88 \%$. Hasil analisis bivariate dan multivariat pada penelitian menyatakan tidak ada hubungan antara penghasilan dengan perilaku merokok elektronik. Penelitian ini tidak sejalan dengan penelitian Istiqomah et al (2016) dan Stallings-smith and Ballantyne (2019) yang menyatakan penghasilan berhubungan dengan penggunaan rokok elektronik. Namun pendapat lain terdapat pada penelitian Friedman and Horn (2018) menyatakan bahwa penghasilan tinggi menurunkan peluang menggunakan rokok elektronik. Adapun asumsi peneliti terkait faktor penghasilan tidak berhubungan dengan penggunaan rokok elektronik dikarenakan remaja yang menggunakan rokok elektronik cenderung belum produktif untuk bekerja dan mendapatkan penghasilan selain itu dilihat dari intepretasi nilai $\mathrm{p}$ value dipengaruhi oleh besar sampel.

Penghasilan orang tua pada analisis bivariat tidak berhubungan dengan penggunaan rokok elektronik. Proporsi yang menggunakan rokok elektronik pada penelitian adalah yang memiliki penghasilan tinggi hanya 10.53\% sedangkan yang memiliki penghasilan orang tua sedang $25 \%$ dan rendah $23.47 \%$. Penelitian ini tidak sejalan dengan penelitian yang dilakukan oleh Friedman and Horn (2018) yang mengatakan semakin kecil angka kemiskinan akan meningkatkan penggunaan rokok elektronik. Peneliti berasumsi bahwa hasil yang diperoleh dikarenakan sebagian besar orang yang merokok elektronik kedua orangtuanya berpenghasilan rendah maupun sedang. Namun dilihat dari teori Duessenbarry dalam buku Renald Kasalin (2000) mengemukakan bahwa perilaku konsumsi tidak bergantung dengan pendapatan yang miliki, menurut teori tersebut semakin besar pendapatan rumah tangga tidak berbanding lurus dengan konsumsi semakin besar begitu juga sebaliknya, hal ini tidak hanya dipengaruhi oleh perilaku konsumsi namun dipengaruhi oleh hal lain seperti faktor sosial dan gaya hidup (Joharelita, 2017).

Hasil analisis bivariat dan multiavariat pada penelitian ini menunjukan adanya hubungan signifikan uang saku terhadap penggunaan rokok elektronik. Dimana penelitian ini tidak sejalan dengan penelitian yang dilakukan oleh Pitriyanti (2018) yang menyatakan uang saku tidak 
berhubungan dengan penggunaan rokok elektronik karena sebagian besar mahasiswa hanya mencoba rokok elektronik kemungkinan besar mahasiswa tersebut hanya mencoba rokok pada teman yang memiliki rokok elektronik. Peneliti berasumsi bahwa pada penelitian ini menggunakan remaja yang telah menjadi penggunaa rokok elektronik minimal sebulan terakhir artinya kemungkinan besar remaja rata-rata memiliki device untuk merokok. Uang saku yang diberikan orang tua tergantung pada gaya hidup. Penghasilan orang tua yang tinggi belum tentu akan meningkatkan gaya hidup. Gaya hidup dipengaruhi oleh beberapa faktor lain seperti faktor sosial (Joharelita, 2017).

Persepsi positif remaja berhubungan signifikan dengan penggunaan rokok elektronik dan memiliki peluang risiko untuk merokok elektronik 8.25 kali lebih besar dibandingkan persepsi negatif. Hasil penelitian ini serupa dengan hasil Bigwanto et al (2019) menyatakan bahwa persepsi positif tentang rokok elektronik lebih murah, lebih aman, lebih keren, berhubungan dengan penggunaan rokok elektronik. Peningkatan perilaku merokok elektronik menurut hasil penelitian Rominjinsder, et al (2018) disebabkan oleh berbagai persepsi positif terhadap rokok elektronik, penerimaan dari lingkungan sosial, terhindar dari batasan merokok, dan tampilan rokok elektronik yang meningkatkan percaya diri. Dari seluruh remaja yang mempunyai persepsi positif terhadap rokok elektronik sebesar $44.7 \%$, sedangkan remaja yang merokok elektronik memiliki persepsi positif sebesar 62.2\%. Pada penelitian yang dilakukan oleh Alawiyah (2017) persepsi positif terhadap rokok elektronik timbul dikarenakan pengetahuan responden yang masih belum memahami bahaya rokok elektronik, dan alasan mencoba rokok elektronik yaitu ingin berhenti merokok tembakau serta ingin mencoba sensasi baru.

Dilihat dari variabel pengetahuan pengetahuan remaja mengenai rokok elektronik tidak terdapat hubungan yang signifikan terhadap penggunaan rokok elektronik. Hasil ini sejalan dengan penelitian yang dilakukan di Kota Bekasi dimana pengetahuan tidak berhubungan signifikan terhdap perilaku penggunaan rokok elektronik (Hasna et al., 2017). Pada penelitian Pitriyanti (2018) dengan responden mahasiswa di Kota Denpasar, faktor pengetahuan juga tidak berpengaruh terhadap penggunaan rokok elektronik. Peneliti mengansumsikan bahwa dilihat dari hasil penelitian sebagian besar remaja yang merokok elektonik mempunyai pengetahuan baik (25.35\%) namun pengetahuan tidak mempengaruhi penggunaan rokok elektronik hal ini didukung oleh teori yang menyatakan bahwa seseorang mengonsumsi barang atau jasa berdasarkan faktor sosial dan kepuasan suatu objek (Indra et al., 2015).

\section{Faktor Penguat}

Remaja saat ini lebih banyak menggunakan media sosial untuk mencari informasi-informasi. Hal ini dibuktikan dengan presentase remaja yang menggunakan rokok elektronik dan pernah melihat iklan sebesar $35.63 \%$ dan sebesar $39 \%$ iklan tersebut ditemui pada media sosial. Pada penelitian ini didapatkan hasil bahwa iklan rokok elektronik berhubungan signifikan dengan penggunaan rokok elektronik dimana yang terpapar iklan 
berpeluang 3.65 kali lebih tinggi menggunakan rokok elektronik dibandingkan yang tidak terpapar iklan. Hal ini sejalan dengan penelitian di China penggunaan rokok elektronik berhubungan dengan iklan yang di dapat yaitu salah satunya melalui internet sebesar $47.97 \%$ (Wang, et al., 2019). Peneliti berasumsi bahwa saat ini penawaran tentang rokok elektronik semakin gencar. Jika dilihat dari pemasaran rokok elektronik di Denpasar masih banyak ditampilkan melalui media sosial seperti: instagram dan facebook, bebarapa iklan rokok elektronik di instagram mencuri perhatian masyarakat khususnya remaja dengan variasi tampilan uap rokok elektronik dan mengadakan paket hemat untuk seperangkat alat-alat vape. Sugiari (2020) mengatakan bahwa bisnis rokok elektronik di Kota Denpasar saat ini mulai meningkat, adanya peningkatan tersebut tentunya berawal dari promosi rokok elektronik sehingga menjadi peningkatan jumlah konsumen yang menggunakan rokok elektronik. Saat ini terdapat lebih dari 500 Vape Shop di Bali.

Hasil yang didapat dari penelitian ini yaitu faktor keluarga memiliki hubungan yang signifikan terhadap penggunaan rokok elektronik. Dimana remaja yang menggunakan rokok elektronik 36.84\% memiliki keluarga yang merokok elektronik, dan berpeluang meningkatkan pengunaan rokok elektronik 4.17 kali dibandingkan remaja yang tidak memiliki keluarga perokok elektronik. Penelitian ini sejalan dengan penelitian yang dilakukan di Kota Denpasar dengan sasaran mahasiswa bahwa keluarga yang tinggal serumah meningkatkan peluang untuk remaja berperilaku merokok (Pitriyanti, 2018). Dari penelitian ini mendapatkan hasil $27.63 \%$ anggota keluarga yang merokok pernah menawarkan rokok pada anaknya, serta $28.95 \%$ mengatakan jiwa ditawari merokok dapat mendorong untuk mencoba rokok elektronik.

Hasil penelitian menunjukan pengguna rokok elektronik $29.92 \%$ mempunyai teman yang merokok, sedangkan yang tidak memiliki teman merokok hanya $10.81 \%$. Faktor teman sebaya berhubungan dengan penggunaan rokok elektronik dimana, remaja yang memiliki teman merokok berpeluang meningkatkan 4.77 kali penggunaan rokok elektronik dibandingkan remaja yang tidak memiliki teman yang merokok elektronik. Penelitian ini sejalan dengan penelitian di Kota Bekasi dimana efek teman meningkatkan probabilitas remaja untuk menggunakan rokok (Hasna et al., 2017). Dilihat dari hasil deskriptif remaja yang pernah ditawari merokok oleh temannya sebesar 59\% dan remaja yang ditawari terdorong untuk mencoba rokok elektronik $25.98 \%$. Hal ini menunjukan jika seseorang berperilaku merokok sebagian besar berada pada lingkungan yang sama. Asumsi ini didukung oleh Anggarwati (2014) yang menyatakan bahwa teman sebaya dapat memengaruhi perilaku individu dimana hubungan tersebut dikembangkan dapat mengarah ke hal positif maupun negatif. Selain itu seperti yang diungkapkan Hurluc (2012) dalam Anggarwati (2014) menyatkan bahwa sebagian besar remaja ingin diterima oleh teman-temannya, sering kali diperoleh dengan berperilaku yang menyimpang yaitu dengan merokok. 


\section{Faktor Pemungkin}

Pada analisis bivariat dan multivariat didapatkan hasil bahwa keterjangkauan berhubungan signifikan dengan penggunaan rokok elektronik dimana remaja yang mengatakan terjangkau berpeluang 4.38 kali menggunakan rokok elektronik dibandingkan dengan yang tidak terjangkau. Penelitian ini serupa dengan penelitian di Jakarta bahwa faktor memiliki uang yang cukup, ketersediaan rokok elektronik dan kemudahan mengakses berhubungan dengan penggunaan rokok elektronik (Bigwanto et al., 2019). Selain itu penelitian yang dilakukan di Semarang oleh Istiqomah et al, (2016) bahwa keterjangkauan dapat meningkatkan keinginan menggunakan rokok elektronik. Hal ini disebabkan semakin maraknya penjualan rokok elektronik di online yang memudahkan remaja untuk mengakses rokok elektronik serta maraknya penjulana offline dengan ditandai jumlah toko vape di Bali mencapai lebih dari 500 toko (Sugiari,2020).

\section{Keterbatasan Penelitian}

Keterbatasan penelitian ini diantaranya peneliti tidak mengobservasi secara langsung pengambilan data dikarenakan situasi Covid19. Data dari penelitian ini diperoleh melalui kuesioner online sehingga kemungkinan memiliki information bias yaitu kemungkinan remaja tidak jujur mengisi kuesioner serta tidak memperhatikan setiap detail pertanyaan dari kesioner. Selanjutnya adanya kemungkinan selection bias karena yang mengisi kuesioner ini hanya remaja dengan ciri-ciri tertentu.

\section{SIMPULAN}

Email korespondensi: puspitapirda14@gmail.com
Berdasarkan pemaparan diadatas dapat disimpulkan bahwa proporsi remaja yang menggunakan rokok elektronik di Denpasar saat ini $22.89 \%$. pengguna rokok elektronik lebih banyak pada usia 22-25 tahun (26.55\%), perokok elektronik didominasi oleh kaum laki-laki yaitu $32.20 \%$, rata-rata menyelesaikan pendidikan Sekolah Menengah Atas (20.20\%) dan Perguruan Tinggi (25.49\%). Selanjutnya faktor yang berhubungan dengan penggunaan rokok elektronik yaitu jenis kelamin, uang saku, persepsi, teman sebaya yang menggunakan rokok elektronik, keluarga menggunakan rokok elektronik, keterjangkauan dan uang saku. Adapun faktor yang tidak berhubungan dengan penggunaan rokok elektronik yaitu umur, status pekerjaan, pendidikan terakhir, penghasilan, penghasilan orang tua dan pengetahuan.

\section{SARAN}

Berdasarkan penelitian ini, adapun saran yang dapat dijadikan bahan pertimbangan yaitu: Bagi pemerintah khususnya pengendalian rokok agar memaksimalkan edukasi yang menyasar pada remaja terkait bahaya rokok elektronik agar dapat merubah persepsi terhadap rokok elektronik. Selanjutnya pemerintah agar mempertibangkan membuat kebijakan terkat iklan rokok elektronik pada media sosial.

Karena keterbatasan waktu, dan pengetahuan peneliti, maka disarankan kepada peneliti selanjutnya agar menggunakan pendekatan secara kualitatif untuk meneliti faktor yang memengaruhi penggunaan rokok elektronik. Selanjutnya 
menggali lebih banyak informasi terkait alasan menggunakan rokok elektronik.

\section{DAFTAR PUSTAKA}

Alawiyah, S. S. (2017). Gambaran persepsi tentang rokok elektrik padapara pengguna rokok elektrik dikomunitas vaporizer kota tangerang. Universitas Islam Negeri Syarif Hidayatullah.

Anggarwati, A. (2014). Hubungan Antara Interaksi Teman Sebaya dengan Perilaku Merokok pada Remaja.

Atmojo, W. S. T. (2017). Pengambilan keputusan perokok tembakau yang beralih ke rokok elektrik. Muhammadiyah Surakarta.

Baharuddin (2017). Faktor-Faktor yang Berhubungan dengan Perilaku Merokok Pada Anak Usia Remaja Madya (15-18 Tahun). Universitas Islam Negeri Alauddin.

Bigwanto, M. et al. (2019). 'Determinants of e-cigarette use among a sample of high school students in Jakarta, Indonesia Abstract':, International Journal of Adolescent Medicine and Health, pp. 1-9. doi: 10.1515/ijamh-2019-0172.

BPOM. (2017). Rokok Elektronik di Indonesia.

Edisi Kedu. Direktorat Pengawasan Narkotika, Psikotropika dan Zat Adiktif Deputi Bidang Pengawasan Produk Terapetik dan NAPZA Badan Pengawas Obat dan Makanan Republik Indonesia.

Cooper, M. et al. (2016). 'Social Norms, Perceptions and Dual/Poly Tobacco Use among Texas Youth', Departemen of Health and Human
Service, (January).

doi: 10.5993/AJHB.40.6.8.

Devhy, N. L. P. and Yudari, A. . I. D. H. (2017). 'Faktor Yang Berpengaruh Terhadap Perilaku Merokok Konvensional dan Elektrik Pada Remaja Di Kota Denpasar', Balimedika Journal, pp. 63-72.

Ditjen Bea Cukai. (2011). 'Gambaran Umum Industri Rokok'.

Etter, J.-F. (2010). 'Electronic Cigarettes: A Survey of Users', BMC Public Health, 10.

Fikriyah, S. and Febrijanto, Y. (2012). 'Jurnal STIKES Volume 5, No. 1, Juli 2012', 5(1), pp. 99-109.

Friedman, A. S. and Horn, S. J. L. (2018). 'Socioeconomic Disparities in Electronic Cigarette Use and Transitions from Smoking', Oxford University Press on behalf of the Society for Research on Nicotine and Tobacco. doi: 10.1093/ntr/nty120/5039191.

Hansen, J., Hanewinkel, R. and Morgenstern, M. (2018). 'Electronic cigarette marketing and smoking behaviour in adolescence: a crosssectional study', Institute for Therapy and Health Research, (E-Cigarette), pp. 1-10. doi: 10.1183/23120541.00155-2018.

Hardianti, E. (2017) Pola Pemanfaatan Uang Saku Mahasiswa Departemen Sosiologi Fakultas Ilmu Sosial dan Ilmu Politik Universitas Hasanuddin.

Hasna, F. N. A. El, Cahyo, K. and Widagdo, L. (2017). 'Faktor-Faktor yang 
Berhubungan dengan Penggunaan

Rokok Elektronik pada Perokok

Pemula di SMA Kota Bekasi', Jurnal

Kesehatan Masyarakat, 5(3), pp. 548-557.

Indonesia, P. R. (2003) Peraturan Pemerintah Republik Indonesia Nomor 19 Tahun 2003 Tentang Pengamanan Rokok Bagi Kesehatan.

Indra, M. F., N, Y. H. and Utami, S. (2015). 'Gambaran Psikologis Perokok Tembakau yang Beralih Menggunakan Rokok Elektronik (Vapoizer)', Jurnal Online Mahasiswa Program Studi Ilmu Keperawatan Universitas Riau, 2(2).

Istiqomah, D. R., Cahyo, K. and Indraswari, R. (2016). 'GAYA HIDUP KOMUNITAS ROKOK ELEKTRIK', 4(April).

Joharelita, M. (2017). ‘Pengaruh Pendapatan Orangtua dan Pengetahuan Ekonomi terhdap Perilaku Konsumsi Siswa SMA Negeri 1 Jawai', Jurnal Pendidikan dan Pembelajaranan Khatulistiwa, 6(08), pp. 1-9.

Kesehatan, K. (2013). RISET KESEHATAN DASAR.

Kesehatan, K. (2018). Riskesdas Bali 2018. Bali.

Ketenagakerjaan, U. R. N. 13 T. 2003 tentang (2003). Undang-Undang Republik Indonesia Nomor 13 Tahun 2003 tentang Ketenagakerjaan.

Lee, J. A., Lee, S. and Cho, H. (2017). 'The Relation between Frequency of ECigarette Use and Frequency and Intensity of Cigarette Smoking among South Korean Adolescents', Environmental Research and Public
Health, 14, pp. 1-9. doi: 10.3390/ijerph14030305.

Lian, T. Y. and Dorotheo, U. (2018). The Tobacco Control Atlas ASEAN Region. Fourth Edi. Edited by M. B. Ritthiphakdee. Bangkok Thailand: Southeast Asia Tobacco Control Alliance (SEATCA). Available at: www.seatca.org.

Luh, N. et al. (2017). 'Faktor Yang Berpengaruh Terhadap Perilaku Merokok Konvensional dan Elektrik Pada Remaja Di Kota Denpasar', Balimedika Journal, pp. 63-72.

Nurjanah, M. (2019). Teori Keluarga: Studi Literatur Mitha Nurjanah.

Pitriyanti, L. et al. (2018). 'Factors affecting the use of electronic cigarettes in Udayana University students', 6(2), pp. 88-92. doi: 10.15562/phpma.v6i2.42.

Putra, I. G. N. E. et al. (2017). 'Gambaran Pemahaman, Persepsi, dan Penggunaan Rokok Elektrik pada Siswa Sekolah Menengah Atas di Kota Denpasar', Conference: Indonesian Conference on Tobacco or Health, 4.

Putra, I. W. G. A. E. et al. (2017). 'Pajanan Iklan Rokok dan Opini Remaja di Provinsi Bali terhadap Keberadaan Iklan Rokok', Conference: 4th Indonesian Conference on Tobacco or Health 2017, (May).

Putro, K. Z. (2017). 'Memahami Ciri dan Tugas Perkembangan Masa Remaja', Aplikasia: Jurnal Aplikasi Ilmu-Ilmu Agama, 17, pp. 25-32. 
Romijnders, K. A. G. J. et al. (2018). 'Perceptions and Reasons Regarding E-Cigarette Use among Users and Non-Users: A Narrative Literature Review', Environmental Research and Public Health, pp. 11-22. doi: 10.3390/ijerph15061190.

Shapiro, H. (2018). 'Tidak Ada Api , Tidak Ada Asap : The Global State of Tobacco Harm Reduction 2018 ( Status Global Pengurangan Bahaya', The Global State of Tobacco Harm Reduction, 2018, pp. 17.

Stallings-smith, S. and Ballantyne, T. (2019).

'Ever Use of E-Cigarettes Among Adults in the United States: A CrossSectional Study of Sociodemographic Factors'. doi: $10.1177 / 0046958019864479$.

Sugiari, Luh Putu (2020). Industri Vape Rumahan di Bali Menggeliat di Tengah Dampak Ekonomi Corona. Bisnis Bali\&Nusra 31 Maret 2020. https://bali.bisnis.com/read/2020033 1/538/1220327/industri-vaperumahan-di-bali-menggeliat-di- tengah-dampak-ekonomi-corona.

Tanggal akses: 14 Juni 2020

Sulistyawan, A. (2012). Faktor-Faktor yang Berhubungan dengan Perilaku Merokok Siswa Sekolah Menengah Pertama Negeri 3 Kota Tanggerang Selatan Tahun 2012. Universitas Islam Negeri Syarif Hidayatullah Jakarta.

Sutfin, E. L. et al. (2014). 'Electronic Cigarette Use by College Students Erin', National Institutes of Health, 131(3), pp. 214-221. doi: 10.1016/j.drugalcdep.2013.05.001.Ele ctronic.

Wahyudi, A. Y. H. (2017) Pengaruh Uang Saku dan Gaya Hidup Terhadap Minat Menabung.

Wang, X. et al. (2019). 'Perceptions and use of electronic cigarettes among young adults in China', Tobacco Induced Diseases, pp. 1-13.

WHO (World Health Organization). (2020). FCTC. Parties to the WHO Framework Convention on Tobacco Control.Available: https://www.who.int/fctc/cop/en/(A ccessed: 6 January 2020 